\title{
Flavonoid Glycosides and their $p$-Coumaroyl Esters from Campylospermum calanthum Leaves
}

\author{
Savio S. Elo Manga ${ }^{\mathrm{a}}$, Anastasie E. Tih ${ }^{\mathrm{a}}$, Bintou Abderamane ${ }^{\mathrm{b}}$, \\ Raphael T. Ghogomu ${ }^{\mathrm{a}, *}$, Alain Blond ${ }^{\mathrm{c}}$, and Bernard Bodo ${ }^{\mathrm{c}}$ \\ a Faculty of Science, Department of Organic Chemistry, University of Yaounde 1, \\ P. O. Box 812, Yaounde, Cameroon. E-mail: ghogomut@uy1.uninet.cm \\ b Faculté des Sciences, Université de Ndjamena, P. O. Box 127, Ndjamena, Tchad \\ c Laboratoire de Chimie des Substances Naturelles, Muséum National d'Histoire \\ Naturelle, 63 Rue Buffon, 75005 Paris, France \\ * Author for correspondence and reprint requests \\ Z. Naturforsch. 67c, 233-243 (2012); received August 19, 2011/January 20, 2012
}

Six new compounds, comprising three flavonoid glycosides and their respective coumaroyl esters, have been isolated and characterized from the methanol extract of the leaves of Campylospermum calanthum, along with three known flavonoid aglycones, 7- $O$-methyl apigenin (1), 7-O-methyl luteolin (2), and 7-O-methyl quercetin (3). Their structures were elucidated based on chemical evidence as well as spectroscopic analysis including $1 \mathrm{D}$ and 2D NMR $\left({ }^{1} \mathrm{H}-{ }^{1} \mathrm{H}\right.$ COSY, HSQC, HMBC, and NOESY) spectroscopy and by comparing their spectral data with those reported for related compounds.

Key words: Campylospermum calanthum, Ochnaceae, Flavonoid Glycosides, Coumaroyl Esters

\section{Introduction}

The tropical and subtropical genus Campylospermum is widely represented in Latin America, West Africa, China, and Southern Asia with at least 480 identified species (Zhang and Amaral, 2007). Among the species found in Cameroon, Campylospermum calanthum Teigh grows as a small tree in secondary forests in the southern and eastern regions of the country where the indigenes prepare alcohol decoctions from either the adult leaves or the stem bark against digestive and cardiac disorders. No phytochemical investigation on this species has been reported. This report deals with the characterization of the constituents of the leaf extract of Campylospermum calanthum from which three new flavonoid glycosides and their coumaroyl esters were isolated and characterized by spectroscopic and chemical evidence; they were named campylospermosides A, B, C, D, E, and F, respectively.

\section{Results and Discussion}

The gum obtained from the methanolic extract of adult leaves of $C$. calanthum after washing with warm ethyl acetate and removal of the solvent from the soluble portion gave the crude extract which was further divided into parts $\mathrm{A}$ and $\mathrm{B}$. Part A was completely hydrolyzed with aqueous hydrochloric acid and evaporated to dryness under vacuum. The residue was washed with ethyl acetate. The soluble portion was evaporated to dryness to give an organic phase, while the insoluble portion, taken up in water and acetone added, yielded a precipitate which was identified from its NMR spectrum and optical rotation as the lone sugar in the structure, D-glucose. The purification of the organic phase led to the isolation of four compounds identified, respectively, as the known flavonoid methyl ethers: 7-O-methyl apigenin (1) (Park et al., 2006), 7-O-methyl luteolin (2) (Sharaf et al., 2000), and 7-O-methyl quercetin (3) (Shen and Theander, 1985), as well as $p$-E-coumaric acid (10) (Bhat et al., 2005).

Part B of the crude extract was subjected to different chromatographic procedures including gel permeation fractionation on a Sephadex LH20 column and repeated chromatography on a silica gel support to give more aglycones $\mathbf{1 - 3}$ and in addition three new flavonoid glycosides, 4-6, and their respective $p$-E-coumaroyl esters, 7-9, as amorphous solids.

Campylospermoside A (4) is a flavonoid glycoside, since it responds positively to both the flavo- 
noid (Mabry et al., 1970) and Molish (Gupta and Kohli, 2010) test, respectively. A molecular formula of $\mathrm{C}_{22} \mathrm{H}_{22} \mathrm{O}_{10}$ was established for this compound from HR-CIMS data that showed the protonated molecular peak at $\mathrm{m} / \mathrm{z} 447.1286$ (calcd. for $\mathrm{C}_{22} \mathrm{H}_{23} \mathrm{O}_{10}, 447.1291$ ). The UV absorption maxima at $\lambda_{\text {max }} 260$ and $328 \mathrm{~nm}$ suggested the presence of the flavone nucleus in its structure (Gattuso et al., 2007). Its IR spectrum confirmed the presence of the flavone nucleus (Jose et al., 1974), since it displayed absorption bands at $3289 \mathrm{~cm}^{-1}(\mathrm{OH})$, $1640 \mathrm{~cm}^{-1}$ (conjugated double bond), $1618 \mathrm{~cm}^{-1}$ (conjugated and chelated $\gamma$-pyrone carbonyl), and $1602 \mathrm{~cm}^{-1}$ (aromatic ring).

Its ${ }^{1} \mathrm{H}$ NMR spectrum showed that most of the signals observed were very similar to those found in the spectrum of compound $\mathbf{1}$ (Table I) suggesting a close relationship between the two structures. The proton systems identified included the lone proton on ring $\mathrm{C}$ that gave a singlet signal at $\delta_{\mathrm{H}} 6.84 \mathrm{ppm}(\mathrm{H}-3)$, a pair of meta-coupled protons on ring A at $\delta_{\mathrm{H}} 6.43 \mathrm{ppm}(1 \mathrm{H}, \mathrm{d}, J=2.0 \mathrm{~Hz}$, $\mathrm{H}-6)$ and $\delta_{\mathrm{H}} 6.82 \mathrm{ppm}(1 \mathrm{H}, \mathrm{d}, J=2.0 \mathrm{~Hz}, \mathrm{H}-8)$, as well as a multiplet for four protons on the paradisubstituted benzene ring B at $\delta_{\mathrm{H}} 7.92 \mathrm{ppm}(2 \mathrm{H}$, $\mathrm{d}, J=9.0 \mathrm{~Hz}, \mathrm{H}-2$ ' and $\left.\mathrm{H}-6{ }^{\prime}\right)$ and $\delta_{\mathrm{H}} 6.92 \mathrm{ppm}$ $\left(2 \mathrm{H}, \mathrm{d}, J=9.0 \mathrm{~Hz}, \mathrm{H}-3^{\prime}\right.$ and $\left.\mathrm{H}-5^{\prime}\right)$. Also, on ring A, a singlet signal for a strongly chelated peri-hydroxy proton at $\delta_{\mathrm{H}} 13.04 \mathrm{ppm}(1 \mathrm{H}, \mathrm{s}, \mathrm{OH}-5)$ and a three-proton singlet signal of a methoxy group at $\delta_{\mathrm{H}} 3.82 \mathrm{ppm}\left(3 \mathrm{H}, \mathrm{s}, \mathrm{CH}_{3} \mathrm{O}-7\right)$ were observed. These values were consistent with those recorded for 7-O-methyl apigenin (1) (Ghosal and Jaiswal, 1980).

Additional signals corresponded to the protons of a sugar moiety. These included a deshielded doublet signal of the anomeric proton at $\delta_{\mathrm{H}}$ $5.05 \mathrm{ppm}(1 \mathrm{H}, \mathrm{d}, J=7.3 \mathrm{~Hz})$, as well as multiplet signals for four oxymethine protons at $\delta_{\mathrm{H}} 3.56 \mathrm{ppm}$ $(\mathrm{H}-2 "), \delta_{\mathrm{H}} 3.48 \mathrm{ppm}(\mathrm{H}-3 "), \delta_{\mathrm{H}} 3.46 \mathrm{ppm}(\mathrm{H}-4 ")$, and $\delta_{\mathrm{H}} 3.48 \mathrm{ppm}(\mathrm{H}-5 ")$, and two oxymethylene protons at $\delta_{\mathrm{H}} 3.42 \mathrm{ppm}\left(\mathrm{H}-6 \mathrm{a}\right.$ ") and $\delta_{\mathrm{H}} 3.85 \mathrm{ppm}$ (H-6b") as given in Table I. These values clearly confirmed that the sugar contained in the structure of campylospermoside A (4) is glucose. The large coupling constant $(J=7.3 \mathrm{~Hz})$ observed between the anomeric proton and the adjacent $\mathrm{H}-2$ " $\left(\delta_{\mathrm{H}} 3.56 \mathrm{ppm}\right)$ indicated the $\beta$-conformation of the glucopyranosyl ring.

The signals for all 22 carbon atoms required by the molecular formula were clearly observed in the totally decoupled ${ }^{13} \mathrm{C}$ NMR spectrum while the off-resonance spectrum allowed their description as primary, secondary, tertiary, and quaternary carbon atoms. The signals at $\delta_{\mathrm{C}} 181.9 \mathrm{ppm}(\mathrm{s}$, C-4), 163.4 ppm (s, C-2), and 103.2 ppm (d, C-3) confirmed the presence of the flavone nucleus, while those at $\delta_{\mathrm{C}} 100.5 \mathrm{ppm}$ (d, C-1"), $71.6 \mathrm{ppm}$ (d, C-2"), 72.9 ppm (d, C-3"), 74.6 ppm (d, C-4"), $76.0 \mathrm{ppm}$ (d, C-5"), and $60.9 \mathrm{ppm}$ (t, C-6") were consistent with the values of the carbon atoms of glucose (Agarwal, 1989).

The lone methoxy substituent was placed on the C-7 carbon atom since the HMBC spectrum of campylospermoside A (4) showed cross-peaks between the methoxy protons $\left(\delta_{\mathrm{H}} 3.82 \mathrm{ppm}\right)$ and the ring A carbon atom $\mathrm{C}-7\left(\delta_{\mathrm{C}} 163.8 \mathrm{ppm}\right)$ of the aglycone. Also, the anomeric proton doublet $\left(\delta_{\mathrm{H}}\right.$ $5.05 \mathrm{ppm}$ ) showed connection spots with the ring B carbon atom C-4' ( $\left.\delta_{\mathrm{C}} 162.4 \mathrm{ppm}\right)$ thus implying that the glycosidic bond is between the sugar anomeric carbon atom C- 1 " $\left(\delta_{\mathrm{C}} 100.5 \mathrm{ppm}\right)$ and the ring $\mathrm{B}$ carbon atom $\mathrm{C}-4$ ' $\left(\delta_{\mathrm{C}} 162.4 \mathrm{ppm}\right)$ of the aglycone. All given evidence established the structure of campylospermoside A (4) as 7- $\mathrm{O}$-methyl apigenin-4"- $O$ - $\beta$-D-glucopyranoside (Fig. 1 ).

Campylospermoside B (5) is also a flavonoid glycoside since it gives positive results in both the flavonoid and Molish test, respectively. Both the UV and IR spectra of compound $\mathbf{4}$ and campylospermoside B (5) were very similar suggesting that the two compounds have closely related structures. This fact was confirmed as the UV spectrum of campylospermoside B displayed two absorption maxima at $\lambda_{\max } 250$ and $338 \mathrm{~nm}$, respectively, while its IR spectrum had absorption bands for an $\mathrm{OH}$ group $\left(3218 \mathrm{~cm}^{-1}\right)$, a conjugated double bond $\left(1642 \mathrm{~cm}^{-1}\right)$, and a chelated $\gamma$-pyrone carbonyl group $\left(1618 \mathrm{~cm}^{-1}\right)$. This data also suggested that the aglycone is a flavone. With the molecular formula $\mathrm{C}_{22} \mathrm{H}_{22} \mathrm{O}_{11}$ deduced from HRCIMS data where the pseudomolecular ion appeared at $m / z 463.1232$ (calcd. for $\mathrm{C}_{22} \mathrm{H}_{23} \mathrm{O}_{11}$, 463.1240) this glycoside has one oxygen atom more than compound 4.

The analysis of the $1 \mathrm{D}$ and $2 \mathrm{D}$ COSY spectra of compound $\mathbf{4}$ and campylospermoside B (5) also showed many similarities with respect to the corresponding signals of all protons on the glucopyranosyl moiety, as well as those on the rings $\mathrm{A}$ and $\mathrm{C}$ of the flavone nucleus. The main difference observed concerned the signals of the ring $B$ protons, which in compound $\mathbf{4}$, concerned four protons on the para-disubstituted benzene 


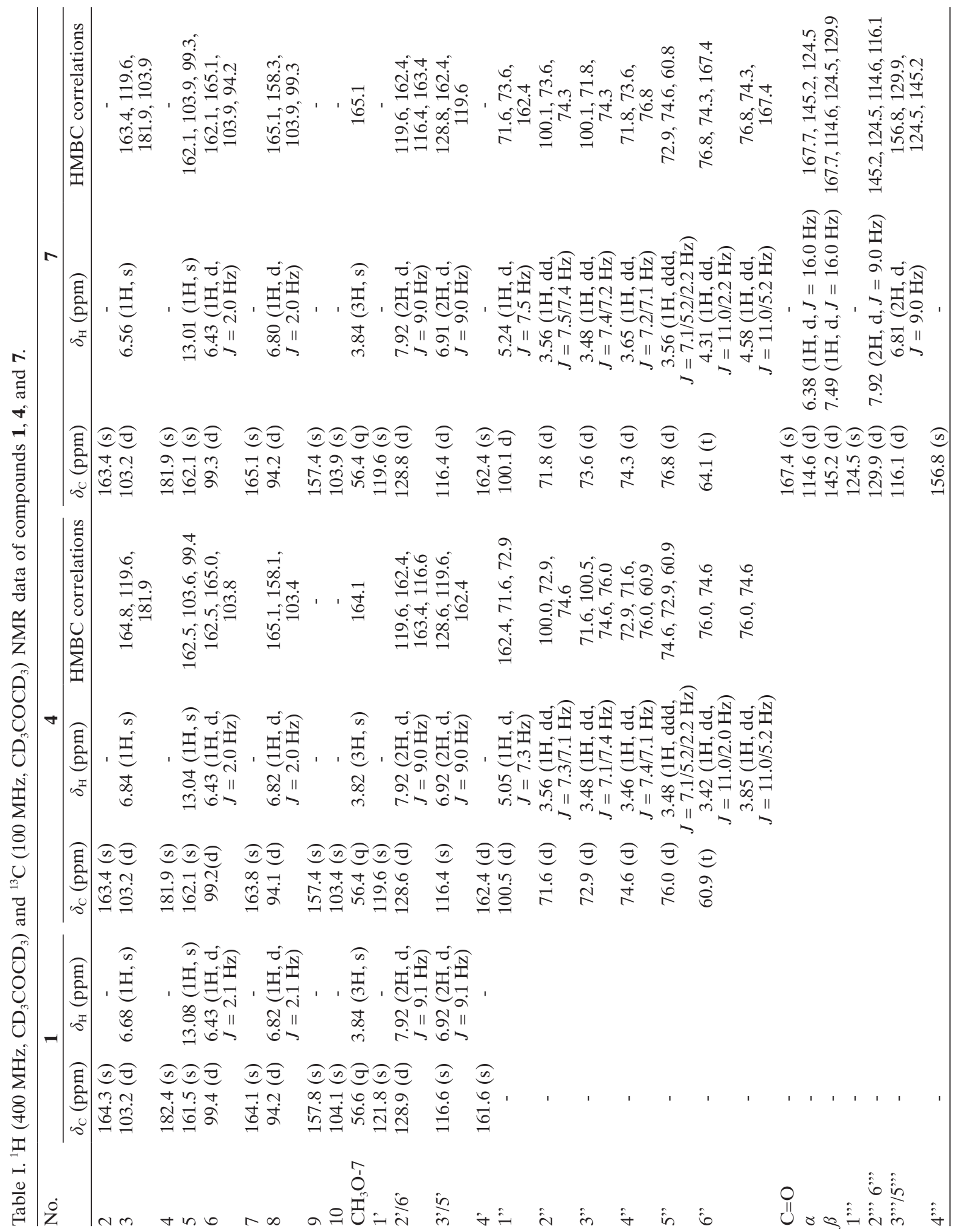


<smiles>[R]Oc1ccc(-c2oc3cc(OC)cc(O)c3c(=O)c2[R])cc1[R]</smiles>

$1 \quad \mathrm{R}^{1}=\mathrm{R}^{2}=\mathrm{R}^{3}=\mathrm{H}$

$2 \quad \mathrm{R}^{1}=\mathrm{R}^{3}=\mathrm{H}, \mathrm{R}^{2}=\mathrm{OH}$

$3 \quad \mathrm{R}^{1}=\mathrm{R}^{2}=\mathrm{OH}, \mathrm{R}^{3}=\mathrm{H}$

$4 \quad \mathrm{R}^{1}=\mathrm{R}^{2}=\mathrm{H}, \mathrm{R}^{3}=$ glucopyranosyl

$5 \quad \mathrm{R}^{1}=\mathrm{H}, \mathrm{R}^{2}=\mathrm{OH}, \mathrm{R}^{3}=$ glucopyranosyl

$6 \quad \mathrm{R}^{1}=\mathrm{R}^{2}=\mathrm{OH}, \mathrm{R}^{3}=$ glucopyranosyl

$7 \mathrm{R}^{1}=\mathrm{R}^{2}=\mathrm{H}, \mathrm{R}^{3}=6$ '”- $p$-E-coumaroyl glucopyranosyl

$8 \quad \mathrm{R}^{1}=\mathrm{H}, \mathrm{R}^{2}=\mathrm{OH}, \mathrm{R}^{3}=6$ '”- $p$-E-coumaroyl glucopyranosyl

$9 \quad \mathrm{R}^{1}=\mathrm{R}^{2}=\mathrm{OH}, \mathrm{R}^{3}=6$ ' $-p$-E-coumaroyl glucopyranosyl
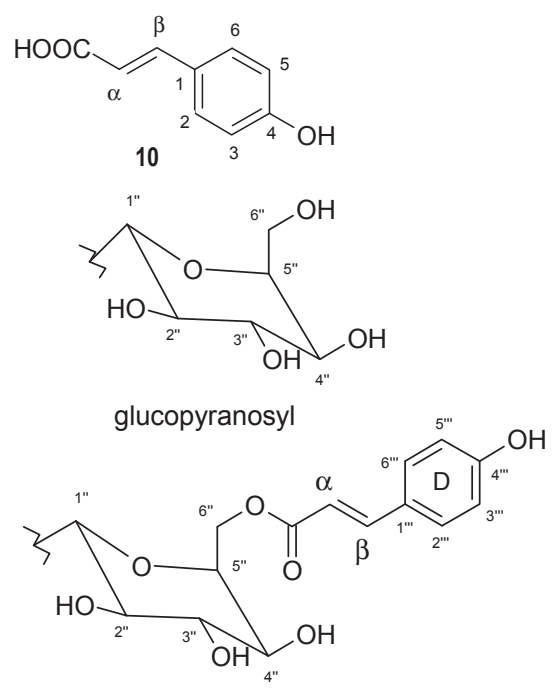

6 "-p-E-coumaroylglucopyranosyl

Fig. 1. Chemical structures of the flavonoid derivatives $\mathbf{1 - 1 0}$.

ring responsible for the signals at $\delta_{\mathrm{H}} 7.92 \mathrm{ppm}$ $\left(2 \mathrm{H}, \mathrm{d}, J=9.0 \mathrm{~Hz}, \mathrm{H}-2^{\prime}\right.$ ' and $\mathrm{H}-6$ ') and $\delta_{\mathrm{H}} 6.92 \mathrm{ppm}$ $\left(2 \mathrm{H}, \mathrm{d}, J=9.0 \mathrm{~Hz}, \mathrm{H}-3^{\prime}\right.$ and $\left.\mathrm{H}-5^{\prime}\right)$, but which in campylospermoside B (5) were replaced by a three-proton system with ortho/meta substitution of the signals which appeared at $\delta_{\mathrm{H}} 7.36 \mathrm{ppm}(\mathrm{H}-$ $\left.2^{\prime}\right), \delta_{\mathrm{H}} 6.94 \mathrm{ppm}\left(\mathrm{H}-5^{\prime}\right)$, and $\delta_{\mathrm{H}} 7.60 \mathrm{ppm}\left(\mathrm{H}^{\prime} 6^{\prime}\right)$. This indicated that the ring B proton $\mathrm{H}-3{ }^{\prime}\left(\delta_{\mathrm{H}}\right.$ $6.92 \mathrm{ppm}$ ) of the aglycone in compound 4 has been replaced by a hydroxy group in campylospermoside B (5) thus forming an ortho-dioxygenated function at positions 3' and 4' of ring B and identifying 7-O-methyl luteolin (2) as aglycone and thus suggesting that the structure of campylospermoside B (5) is 7-O-methyl luteolin4'- $O-\beta$-D-glucopyranoside (Fig. 1 ).

This structure was confirmed by the HSQC and HMBC spectra in which the observed cross-peaks led to the assignment of the chemical shifts of all protons and carbon atoms in the molecule of compound 5 (Table II). The chemical shifts of the ortho-dioxygenated carbon atoms C-3' and C-4' in ring B appeared at $\delta_{\mathrm{C}} 146.6$ and $150.1 \mathrm{ppm}$, respectively. While both values were very close to those observed in the ${ }^{13} \mathrm{C}$ NMR spectra of luteolin derivatives, the chemical shifts of the carbon atoms of the sugar moiety were those recorded for glucose (Agarwal, 1989).
The anomeric proton of glucose $\left(\delta_{\mathrm{H}} 5.09 \mathrm{ppm}\right)$ was correlated with the carbon atom C-4' $\left(\delta_{\mathrm{C}}\right.$ $150.1 \mathrm{ppm}$, ring $\mathrm{B})$, confirming the fact that the glycosidic bond is between the carbon atom C-1" of glucose and the carbon atom C-4' of the aglycone. The large coupling constant $(J=7.5 \mathrm{~Hz})$ of the anomeric proton $\mathrm{H}-1$ " $\left(\delta_{\mathrm{H}} 5.09 \mathrm{ppm}\right)$ with the proton $\mathrm{H}-2$ " $\left(\delta_{\mathrm{H}} 3.55 \mathrm{ppm}\right)$ of the sugar moiety indicated once more the $\beta$-configuration of the glycosidic bond in the pyranosyl ring.

Campylospermoside $\mathrm{C}(\mathbf{6})$ is the third flavonoid glycoside with the molecular formula $\mathrm{C}_{22} \mathrm{H}_{22} \mathrm{O}_{12}$ established also from HR-CIMS data where the protonated molecular ion was observed at $\mathrm{m} / \mathrm{z}$ 479.1192 (calcd. for $\mathrm{C}_{22} \mathrm{H}_{23} \mathrm{O}_{12}, 479.1189$ ). This compound thus has an oxygen atom more than compound 5. Both its IR and UV spectra were very similar to those of compounds $\mathbf{3}$ and $\mathbf{5}$, as they also had, respectively, two absorption maxima at $\lambda_{\max } 260$ and $330 \mathrm{~nm}$ and absorption bands for an OH group $\left(3198 \mathrm{~cm}^{-1}\right)$, a conjugated double bond $\left(1642 \mathrm{~cm}^{-1}\right)$, and a chelated $\gamma$-pyrone carbonyl group $\left(1620 \mathrm{~cm}^{-1}\right)$ indicating that a flavonol moiety is included in the structure of campylospermoside C (Gattuso et al., 2007).

The ${ }^{1} \mathrm{H}$ and ${ }^{13} \mathrm{C}$ NMR spectra of campylospermoside $\mathrm{C} \mathrm{(6)}$ and compound $\mathbf{5}$ were very similar, apart from the fact that the signal of the proton 


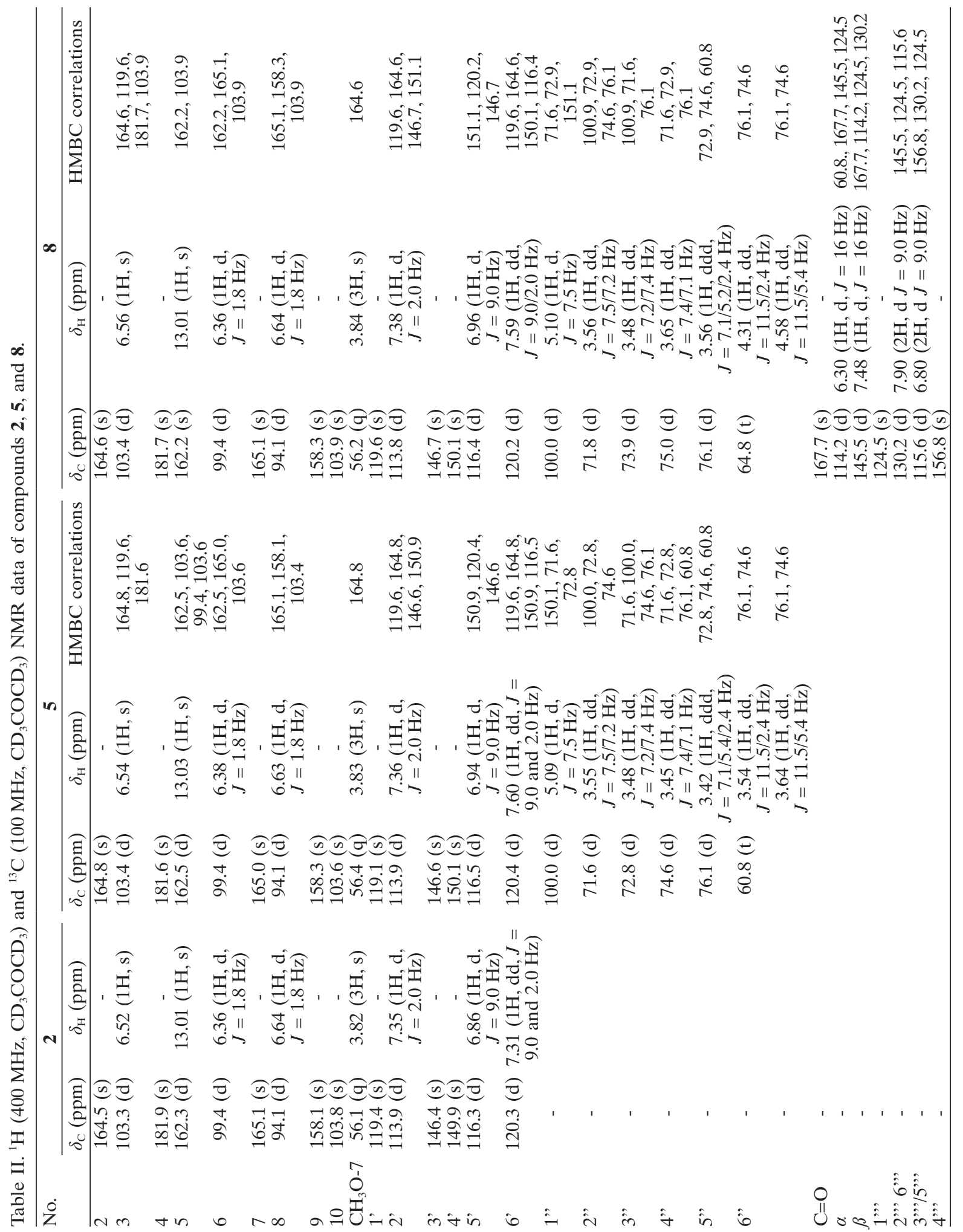


H-3 on ring $\mathrm{C}$, which appeared as a singlet at $\delta_{\mathrm{H}}$ $6.54 \mathrm{ppm}$ in the spectrum of compound $\mathbf{5}$, was absent in that of campylospermoside C (6). This suggests that the aglycone in campylospermoside $\mathrm{C}$ is 7-O-methyl quercetin (3).

This fact was confirmed by the complete analysis of its HSQC and HMBC spectra that led to the assignment of the chemical shifts of all protons and carbon atoms in the molecule. The observed signals (Table III) were reasonably the same as those reported for 7-O-methyl quercetin and those of a glucosyl residue in the $\beta$-pyranose conformation (Agarwal, 1989)

Cross-peaks observed between the anomeric proton of glucose $\left(\delta_{\mathrm{H}} 5.09 \mathrm{ppm}\right)$ and the ring B carbon atom C-4' $\left(\delta_{\mathrm{C}} 147.8 \mathrm{ppm}\right)$ showed that the glycosidic bond is once more between the carbon atom C-1" of glucose and the carbon atom C-4' of the aglycone thus establishing the structure of campylospermoside $\mathrm{C}(\mathbf{6})$ as $7-O$-methyl quercetin-4'- $O-\beta$-D-glucopyranoside. NOE difference experiments also showed that the anomeric proton $\mathrm{H}-1$ " $\left(\delta_{\mathrm{H}} 5.09 \mathrm{ppm}\right)$ in compound $\mathbf{6}$ gave NOE values of $12 \%$ and $0 \%$, respectively, with the glucose proton $\mathrm{H}-5,\left(\delta_{\mathrm{H}} 6.94 \mathrm{ppm}\right)$ on one hand and with the ring B proton $\mathrm{H}-2^{\prime}\left(\delta_{\mathrm{H}} 7.77 \mathrm{ppm}\right)$ on the other, confirming the fact that the glycosidic bond is between the sugar carbon atom C-1" and the ring $\mathrm{B}$ carbon atom C-4' of the aglycone and thus confirming the structure of $\mathbf{6}$ (Fig. 1).

Campylospermoside D (7) was assigned the molecular formula $\mathrm{C}_{31} \mathrm{H}_{28} \mathrm{O}_{12}$ from its HR-CI mass spectrum (found for $[\mathrm{M}+\mathrm{H}]^{+} \mathrm{m} / z$ 593.1659, calcd. for $\left.\mathrm{C}_{31} \mathrm{H}_{29} \mathrm{O}_{12}, 593.1646\right)$. Its ${ }^{1} \mathrm{H}$ NMR spectra (1D and $2 \mathrm{D}$ COSY) were equally similar to those of compound $\mathbf{4}$ as they presented the same signals defining all protons on rings $\mathrm{A}$ and $\mathrm{B}$ of the aglycone 7-O-methyl apigenin (1). Even though the chemical shifts of most of the protons of the sugar (glucose) were unchanged, two important differences were observed concerning the anomeric proton (H-1"), that gave a slight downfield signal at $\delta_{\mathrm{H}} 5.24 \mathrm{ppm}$, as well as the methylene protons on the carbon atom C-6", which appeared also deshielded by $\Delta \delta 0.15 \mathrm{ppm}$ compared to those in compound 4.

In addition, signals of a two-protonsystem on a trans-double bond were observed at $\delta_{\mathrm{H}} 6.38 \mathrm{ppm}$ $(1 \mathrm{H}, \mathrm{d}, J=16 \mathrm{~Hz}, \mathrm{H}-\alpha)$ and $7.49 \mathrm{ppm}(1 \mathrm{H}, \mathrm{d}, J=$ $16 \mathrm{~Hz}, \mathrm{H}-\beta)$, as well as a quartet signal for four protons on the second para-disubstituted benzene ring $\mathrm{D}$, which appeared at $\delta_{\mathrm{H}} 6.81 \mathrm{ppm}(2 \mathrm{H}, \mathrm{d}, J=$
$9.0 \mathrm{~Hz}, \mathrm{H}-3$ "' and $\mathrm{H}-5 "$ ") $)$ and $7.92 \mathrm{ppm}(2 \mathrm{H}, \mathrm{d}$, $J=9.0 \mathrm{~Hz}, \mathrm{H}-2$ " " and H-6" "). This information completed that of the presence of a conjugated ester carbonyl absorption at $1732 \mathrm{~cm}^{-1}$ in its IR spectrum to suggest the presence of a coumaroyl ester function adjacent to the methylene protons H-6a" $\left(\delta_{\mathrm{H}} 4.31 \mathrm{ppm}\right)$ and H-6b" ( $\left.\delta_{\mathrm{H}} 4.58 \mathrm{ppm}\right)$ of the glucose moiety and established the structure of campylospermoside D (7) as 7-O-methyl apigenin-4'- $O-\beta$-D-(6"'- $p$ - $E$-coumaroyl) glucopyranoside.

The correlations observed in the HMBC spectrum of campylospermoside D (7) confirmed the presence of the coumaroyl group in its structure as both the conjugated ester carbonyl carbon atom $\left(\delta_{\mathrm{C}} 167.4 \mathrm{ppm}\right)$ and the carbon atom C-1"' $\left(\delta_{\mathrm{C}} 124.5 \mathrm{ppm}\right)$ of the para-disubstituted benzene ring $\mathrm{D}$ showed cross-peaks with the two double bond protons $\mathrm{H}-\alpha\left(\delta_{\mathrm{H}} 6.38 \mathrm{ppm}\right)$ and $\mathrm{H}-\beta$ $\left(\delta_{\mathrm{H}} 7.49 \mathrm{ppm}\right)$. Also other connection spots were observed between the methylene protons, $\mathrm{H}_{\mathrm{a}}-6$ " $\left(\delta_{\mathrm{H}} 4.31 \mathrm{ppm}\right)$ and $\mathrm{H}_{\mathrm{b}}-6 "\left(\delta_{\mathrm{H}} 4.58 \mathrm{ppm}\right)$ on the carbon atom C-6" of glucose and the conjugated ester carbonyl carbon atom $\left(\delta_{\mathrm{C}} 167.4 \mathrm{ppm}\right)$ showing that the ester bond is between the coumaroyl carbonyl carbon atom ( $\left.\delta_{\mathrm{C}} 167.4 \mathrm{ppm}\right)$ and the methylene carbon atom of glucose at $\delta_{\mathrm{C}} 64.1 \mathrm{ppm}$. The complete assignments of the chemical shifts of the carbon atoms in the molecule confirmed the carbon skeleton of structure 7. These values listed in Table I include those of the 7-O-methyl apigenin carbon skeleton (Agarwal, 1989) as the aglycone. The chemical shift of the anomeric carbon atom of the sugar found at $\delta_{\mathrm{C}} 100.1 \mathrm{ppm}$ corresponded to that of glucose. The coumaroyl ester carbonyl carbon atom appeared at $\delta_{\mathrm{C}} 167.4 \mathrm{ppm}$ while the double bond carbon atoms gave signals at $\delta_{\mathrm{C}} 114.6 \mathrm{ppm}(\mathrm{C}-\alpha)$ and $\delta_{\mathrm{C}} 145.2 \mathrm{ppm}(\mathrm{C}-\beta)$.

Campylospermoside E (8) is also a flavonoid glycoside derivative. Its IR spectrum is very similar to that of compound 7, since it displayed absorption bands for the same functional groups including hydroxy groups $\left(3431 \mathrm{~cm}^{-1}\right)$, a conjugated ester carbonyl group $\left(1726 \mathrm{~cm}^{-1}\right)$, a chelated conjugated ketone carbonyl group $\left(1616 \mathrm{~cm}^{-1}\right)$, a conjugated double bond $\left(1632 \mathrm{~cm}^{-1}\right)$, and aromatic rings $\left(1603 \mathrm{~cm}^{-1}\right)$. These values suggested that campylospermoside E (8) is also a coumaroyl ester of a flavone glycoside. With the molecular formula $\mathrm{C}_{31} \mathrm{H}_{28} \mathrm{O}_{13}$ established from HR-CIMS measurements (observed for $[\mathrm{M}+\mathrm{H}]^{+} \mathrm{m} / \mathrm{z}$ 609.1615, 


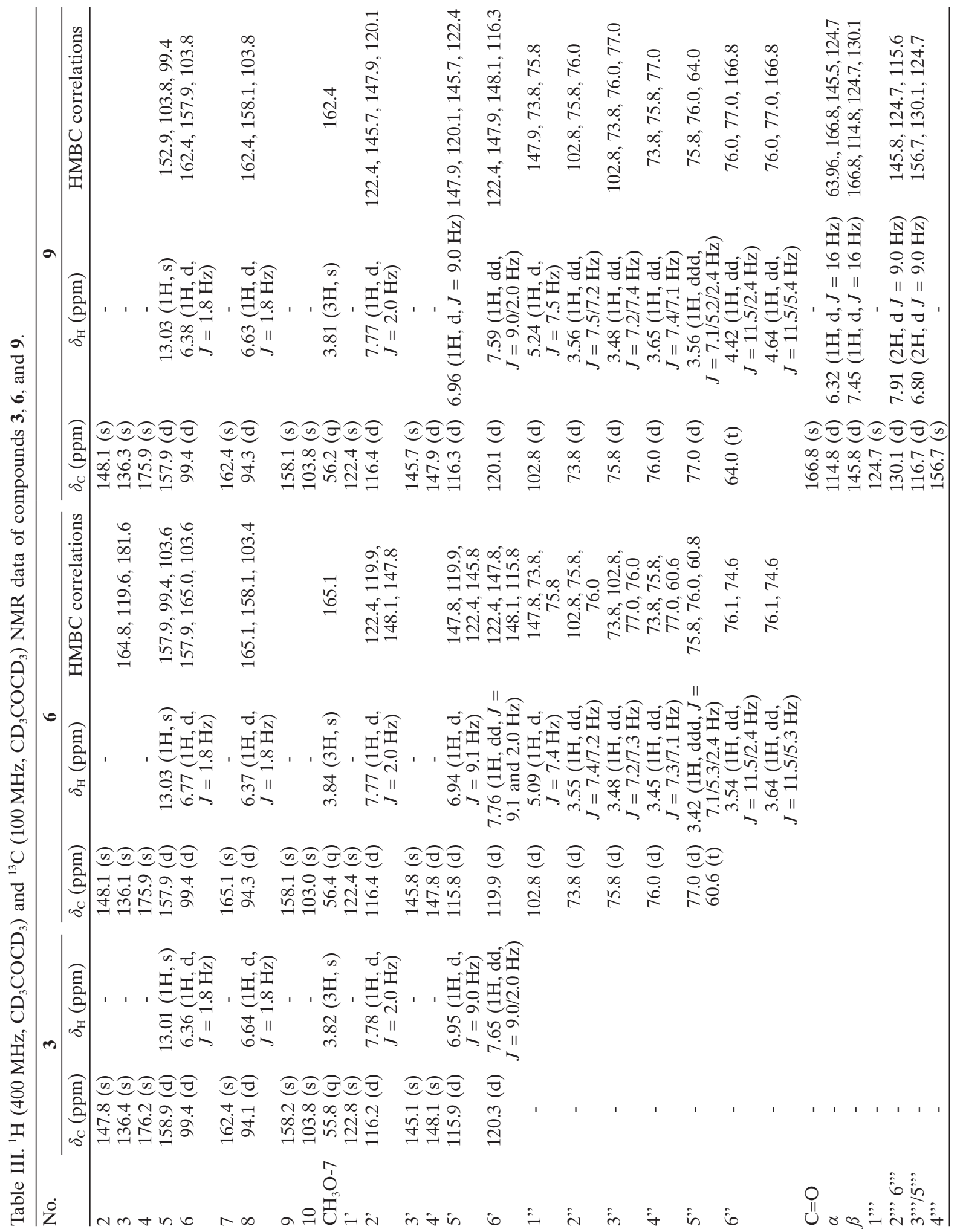


calcd. for $\mathrm{C}_{31} \mathrm{H}_{29} \mathrm{O}_{13}, 609.1608$ ), it has one oxygen atom more than compound 7.

Even though the ${ }^{1} \mathrm{H}$ NMR spectrum (Table II) of campylospermoside $\mathrm{E}$ and compound $\mathbf{7}$ had very similar signals for the proton systems on rings $\mathrm{A}$ and $\mathrm{C}$, as well as those on the sugar residue and the para-coumaroyl group, important differences were noticed concerning the signals of the ring $\mathrm{B}$ protons. The para-disubstituted benzene ring bearing four protons in compound 7 had been replaced by a relatively shielded three-proton system with ortho/meta substitution in campylospermoside $\mathrm{E}(\mathbf{8})$ the signals of which appeared at $\delta_{\mathrm{H}} 7.38 \mathrm{ppm}(1 \mathrm{H}, \mathrm{d}, J=2.0 \mathrm{~Hz}, \mathrm{H}-2$ ') $6.96 \mathrm{ppm}\left(1 \mathrm{H}, \mathrm{d}, J=9.0 \mathrm{~Hz}, \mathrm{H}-5^{\prime}\right)$, and $7.59 \mathrm{ppm}$ $\left(1 \mathrm{H}, \mathrm{dd}, J=9.0\right.$ and $\left.2.0 \mathrm{~Hz}, \mathrm{H}-6{ }^{\prime}\right)$. The additional oxygen atom in the molecular formula again must have been engaged in a hydroxy group with the proton $\mathrm{H}-3$ ' to give 7-O-methyl luteolin as the aglycone. On the basis of the above evidence, the structure of campylospermoside $\mathrm{E}(\mathbf{8})$ was determined as 7-O-methyl luteolin-4'-O- $\beta$-D-(6"'- $-E-E$ coumaroyl) glucopyranoside.

The analysis of the HMBC spectrum of campylospermoside E (8) enabled the complete assignments of the chemical shifts of all carbon atoms required by the molecular formula which were found consistent with the proposed structure 8 .

Campylospermoside $\mathrm{F}$ (9) was assigned the molecular formula $\mathrm{C}_{31} \mathrm{H}_{28} \mathrm{O}_{14}$ from HR-CIMS analysis (observed $[\mathrm{M}+\mathrm{H}]^{+} \mathrm{m} / \mathrm{z}$ 625.1542, calcd. for $\left.\mathrm{C}_{31} \mathrm{H}_{29} \mathrm{O}_{14}, 625.1557\right)$, which showed that this compound has one oxygen atom more than compound 8. Its IR spectrum was very similar to those of compounds $\mathbf{7}$ and $\mathbf{8}$ as it displayed absorption bands for a hydroxy group $\left(3334 \mathrm{~cm}^{-1}\right)$, a conjugated and chelated carbonyl ketone group $\left(1618 \mathrm{~cm}^{-1}\right)$, a conjugated ester carbonyl group $\left(1724 \mathrm{~cm}^{-1}\right)$, a conjugated double bond $\left(1632 \mathrm{~cm}^{-1}\right)$ and aromatic rings $\left(1601 \mathrm{~cm}^{-1}\right)$. This clearly implied that campylospermoside F (9) is also a coumaroyl ester of a flavonoid glycoside.

Confirmation was obtained from the analysis of the ${ }^{1} \mathrm{H}$ NMR spectrum of campylospermoside F (9) (Table III) in which the chemical shifts of protons of the coumaroyl ester substituent appeared at $\delta_{\mathrm{H}} 6.32 \mathrm{ppm}(1 \mathrm{H}, \mathrm{d}, J=16.0 \mathrm{~Hz}, \mathrm{H}-\alpha)$, $7.45 \mathrm{ppm}(1 \mathrm{H}, \mathrm{d}, J=16.0 \mathrm{~Hz}, \mathrm{H}-\beta), 7.91 \mathrm{ppm}(2 \mathrm{H}$, $\mathrm{d}, J=9.0 \mathrm{~Hz}, \mathrm{H}-2$ "' and H-6"'), and $6.80 \mathrm{ppm}(2 \mathrm{H}$, $\mathrm{d}, J=9.0 \mathrm{~Hz}, \mathrm{H}-3$ "' and $\mathrm{H}-5$ "'). Equally, its ${ }^{13} \mathrm{C}$ NMR spectrum had the signals of the coumaroyl double bond carbons atoms at $\delta_{\mathrm{C}} 114.8 \mathrm{ppm}(\mathrm{C}-\alpha)$ and $145.8 \mathrm{ppm}(\mathrm{C}-\beta)$, the ester carbonyl carbon atom at $\delta_{\mathrm{C}} 166.8 \mathrm{ppm}(\mathrm{C}=\mathrm{O})$, and the C-6" carbon atom of the glucose moiety at $\delta_{\mathrm{C}} 64.0 \mathrm{ppm}$. Also the signals at $\delta_{\mathrm{H}} 6.38 \mathrm{ppm}(\mathrm{H}-6), 6.63 \mathrm{ppm}$ (H-8), 7.77 ppm (H-2'), $6.96 \mathrm{ppm}\left(\mathrm{H}^{-}{ }^{\prime}\right), 7.59 \mathrm{ppm}$ ( $\mathrm{H}-6$ '), and $3.81 \mathrm{ppm}\left(\mathrm{CH}_{3} \mathrm{O}-7\right)$ in its ${ }^{1} \mathrm{H}$ NMR spectrum as well as those at $\delta_{\mathrm{C}} 99.4 \mathrm{ppm}(\mathrm{C}-6)$, $94.3 \mathrm{ppm}(\mathrm{C}-8), 116.4 \mathrm{ppm}\left(\mathrm{C}-2^{\prime}\right), 116.3 \mathrm{ppm}$ (C5'), $120.1 \mathrm{ppm}\left(\mathrm{C}^{\prime} 6^{\prime}\right)$, and $56.2 \mathrm{ppm}\left(\mathrm{CH}_{3} \mathrm{O}-7\right)$ in its ${ }^{13} \mathrm{C}$ NMR spectrum showed that the aglycone is 7-O-methyl quercetin.

HMBC correlations (Table III) showed crosspeaks indicating that the coumaroyl ester carbonyl carbon atom at $\delta_{\mathrm{C}} 166.8 \mathrm{ppm}$ is connected to the double bond proton $\mathrm{H}-\alpha\left(\delta_{\mathrm{H}} 6.32 \mathrm{ppm}\right)$ as well as both protons of the oxymethylene carbon atom of glucose $\mathrm{H}_{\mathrm{a}}-6$ " $\left(\delta_{\mathrm{H}} 4.42 \mathrm{ppm}\right)$ and $\mathrm{H}_{\mathrm{b}}-6$ " $\left(\delta_{\mathrm{H}} 4.64 \mathrm{ppm}\right)$. The above evidence led to the structure 7-O-methyl quercetin-4'- $O-\beta$-D-(6"- $p$ $E$-coumaroyl) glucopyranoside for campylospermoside F (9). The other observed HMBC correlations led to the complete assignment of the chemical shifts of all carbon atoms in the molecule, and the values obtained were consistent with the proposed structure.

This report on the flavone and flavonol glycosides and their coumaroyl esters from Campylospermum calanthum adds to the rich diversity of the secondary metabolites found in the genus Campylospermum, since previous investigations on other species led to the characterization of biflavonoids (Elo Manga et al., 2009; Ndongo et al., 2010), nitrile glycosides (Abouem á Zintchem et al., 2008), and alkaloids (Ndongo et al., 2010). The botanical distinction between the genera Campylospermum and Ouratea in the subtribe Ouratinae is still not clear as many plants named in either of the genera have synonyms in the other.

Phytochemical studies carried out on some species of the genus Ouratea have revealed that this genus is very rich mainly in biflavonoids (Carbonezi et al., 2007; Carvalho et al., 2000, 2008; Daniel et al., 2005; Felicio et al., 2001, 2004; Grynberg et al., 2002; Moreira et al., 1999; Mbing et al., 2003; Nascimento et al., 2009; Ngo-Mbing et al., 2006; Pegnyemb et al., 2005; Velandia et al., 2002; Zintchem et al., 2007). Comparing the constituents of both genera, there is a tendency to admit that their chemical compositions are different and can be used to clarify this classification. 
Despite these results, it is premature to draw a clear conclusion that will help to distinguish between plants belonging to either of the genera since many other species are still to be investigated.

\section{Experimental}

\section{General experimental procedures}

UV spectra were recorded on a KontronUvikon 930 spectrophotometer (San Diego, CA, USA). IR spectra were obtained, using transparent $\mathrm{KBr}$ discs, on a JASCO FTIR-3000E spectrometer (Tokyo, Japan). Optical rotations were measured on a Perkin-Elmer 341 polarimeter (Überlingen, Germany). HR-CIMS was run on a Riber Nermag $\mathrm{V}_{3.0}$ instrument (Rueil-Malmaison, France), using $\mathrm{NH}_{3}$ as ionizing gaz. The $400-\mathrm{MHz}$ ${ }^{1} \mathrm{H}$ and $100-\mathrm{MHz}{ }^{13} \mathrm{C}$ NMR spectra of solutions of compounds in $\mathrm{CD}_{3} \mathrm{COCD}_{3}$ were recorded on a Bruker WM400 spectrometer (Rheinstetten, Germany). Chemical shifts are expressed in $\delta$ (ppm) with tetramethylsilane (TMS) as reference and coupling constants $(J)$ in Hertz. For HMBC spectra, the delay was $70 \mathrm{~ms}$ with $J_{\mathrm{CH}} \sim 7 \mathrm{~Hz}$. Sephadex LH20 (Pharmacia, Fine Chemicals, Uppsala, Sweden) and Kieselgel 60 (mesh 0.063D, 0.200 mm; Merck, Darmstadt, Germany) were used for column chromatography. Thin-layer chromatography (TLC) was carried out on precoated fluorescent silica gel $60 \mathrm{~F}_{254}$ aluminium sheets (Merck) and developed in the eluent mixture $\mathrm{CH}_{2} \mathrm{Cl}_{2} / \mathrm{MeOH}$ $(10: 1, \mathrm{v} / \mathrm{v})$. TLC chromatograms were visualized by spraying plates with $5 \% \mathrm{H}_{2} \mathrm{SO}_{4}$, after which they were heated in an oven at $60{ }^{\circ} \mathrm{C}$ for $15 \mathrm{~min}$. Preparative TLC plates on glass support were prepared using fluorescent silica gel $\left(\mathrm{F}_{254}\right)$, and, after applying the mixture for separation, they were developed in the same solvent system as above and visualized with a UV lamp of the wavelength $254 \mathrm{~nm}$. Bands resulting from the separation were isolated, scraped off, and eluted with methanol to obtain pure compounds.

\section{Plant material}

The leaves of Campylospermum calanthum (Ochnaceae), harvested in January 2007 on Mount Kala in the Yaounde neighbourhood of the central region of Cameroon, were identified by Victor Nana, botanist at the National Herbar- ium, Yaounde, Cameroon, where a voucher specimen (no. VN 2124) was deposited.

\section{Extraction and isolation}

Air-dried leaves of Campylospermum calanthum were hand-crushed and ground with a grinding mill into a fine powder $(0.5 \mathrm{~kg})$ which was extracted with cold methanol in an iron tank equipped with a mechanic stirrer. After removal of the solvent, the obtained gum (46.2 g) was washed with warm ethyl acetate, and the soluble portion was evaporated to give a dark crude extract $(25 \mathrm{~g})$ which was divided into two parts, A $(5 \mathrm{~g})$ and $\mathrm{B}(20 \mathrm{~g})$.

Part A (5 g) was completely hydrolyzed under reflux with aqueous hydrochloric acid, $(10 \%$, $25 \mathrm{ml}$ ) in a $50-\mathrm{ml}$ round-bottom flask for $4 \mathrm{~h}$ after which the reaction medium was evaporated to dryness under vacuum. Then, the residue was taken up in ethyl acetate $(3 \times 10 \mathrm{ml})$ to give the organic phase. The insoluble portion left was dissolved in water $(10 \mathrm{ml})$ forming the aqueous phase. Acetone $(10 \mathrm{ml})$ was added to the former which resulted in the precipitation of a sugar which was identified as D-glucose on the basis of its NMR spectra and its optical rotation. The organic phase was then purified by repeated column chromatography over a silica gel support with the eluent mixture $\mathrm{CH}_{2} \mathrm{Cl}_{2} / \mathrm{MeOH}(10: 1, \mathrm{v} / \mathrm{v})$ to give four compounds, $\mathbf{1}$ (36 mg), 2 (29 mg), 3 (22 mg), and $\mathbf{1 0}(20 \mathrm{mg})$.

Part B (20 g) was first fractionated by gel filtration on a Sephadex LH20 column with methanol as eluent to give four fractions F1 $(12.5 \mathrm{~g}), \mathrm{F} 2$ (4.5 g), F3 (1.8 g), and F4 (1.2 g). Fraction F4 was subjected to repeated column chromatography on a silica gel support to give more of compounds 1 (18 mg), 2 (16 mg), and 3 (12 mg). Fraction F3 was subjected to preparative TLC developed in the solvent mixture $\mathrm{CH}_{2} \mathrm{Cl}_{2} / \mathrm{MeOH}(10: 1, \mathrm{v} / \mathrm{v})$ and using the technique of multiple migrations to give compounds 4 (24 mg), 5 (17 mg), and 6 (14 mg). Fraction F2 underwent the same purification procedure like fraction F3 to give compounds 7 (18 mg), 8 (16 mg), and 9 (12 mg).

7-O-Methyl apigenin (1): Amorphous yellow powder. - UV $(\mathrm{MeOH}): \lambda_{\max }(\log \varepsilon)=264$ (2.8), $330 \mathrm{~nm}$ (1.2). - IR (KBr): $v_{\max }=3252$, $1648,1624,1605,1596 \mathrm{~cm}^{-1} \cdot-{ }^{1} \mathrm{H}$ NMR $\left(\mathrm{CD}_{3^{-}}\right.$ $\left.\mathrm{COCD}_{3}, 400 \mathrm{MHz}\right)$ and ${ }^{13} \mathrm{C} \mathrm{NMR}\left(\mathrm{CD}_{3} \mathrm{COCD}_{3}\right.$, 
$100 \mathrm{MHz}$ ): see Table I. - HR-CIMS: $m / z=$ 285.0686 (calcd. for $\mathrm{C}_{16} \mathrm{H}_{13} \mathrm{O}_{5} 285.0694$ ).

7-O-Methyl luteolin (2): Amorphous yellow powder. - UV $(\mathrm{MeOH}): \lambda_{\max }(\log \varepsilon)=253(2.8)$, $341 \mathrm{~nm}$ (1.2). - IR (KBr): $v_{\text {max }}=3142,1644$, 1621, 1601, $1599 \mathrm{~cm}^{-1} .-{ }^{1} \mathrm{H}$ NMR $\left(\mathrm{CD}_{3} \mathrm{COCD}_{3}\right.$, $400 \mathrm{MHz})$ and ${ }^{13} \mathrm{C} \mathrm{NMR}\left(\mathrm{CD}_{3} \mathrm{COCD}_{3}, 100 \mathrm{MHz}\right)$ : see Table II. - HR-CIMS: $m / z=301.0556$ (calcd. for $\mathrm{C}_{16} \mathrm{H}_{13} \mathrm{O}_{6} 301.0565$ ).

7-O-Methyl quercetin (3): Amorphous yellow powder. $-\mathrm{UV}(\mathrm{MeOH}): \lambda_{\max }(\log \varepsilon)=258$ (1.3), $332 \mathrm{~nm}$ (1.1). - IR (KBr): $v_{\max }=3285,3048$, 1636, 1620, $1598 \mathrm{~cm}^{-1} .-{ }^{1} \mathrm{H}$ NMR $\left(\mathrm{CD}_{3} \mathrm{COCD}_{3}\right.$, $400 \mathrm{MHz})$ and ${ }^{13} \mathrm{C} \mathrm{NMR}\left(\mathrm{CD}_{3} \mathrm{COCD}_{3}, 100 \mathrm{MHz}\right)$ : see Table III. - HR-CIMS: $m / z=317.0584$ (calcd. for $\mathrm{C}_{16} \mathrm{H}_{13} \mathrm{O}_{7} 317.0592$ ).

Campylospermoside $A$ (4): Amorphous beige powder. $-[\alpha]_{\mathrm{D}}^{20}-46.2^{\circ}$ (c $\left.0.18, \mathrm{MeOH}\right)$. - UV $(\mathrm{MeOH}): \lambda_{\max }(\log \varepsilon)=260$ (3.42), $328 \mathrm{~nm}(1.34)$. IR (KBr): $v_{\max }=3289,3052,1640,1618,1602 \mathrm{~cm}^{-1}$. $-{ }^{1} \mathrm{H}$ NMR $\left(\mathrm{CD}_{3} \mathrm{COCD}_{3}, 400 \mathrm{MHz}\right)$ and ${ }^{13} \mathrm{C} \mathrm{NMR}$ $\left(\mathrm{CD}_{3} \mathrm{COCD}_{3}, 100 \mathrm{MHz}\right)$ : see Table I. - HR-CIMS: $m / z=447.1286$ (calcd. for $\mathrm{C}_{22} \mathrm{H}_{23} \mathrm{O}_{10} 447.1291$ ).

Campylospermoside $\mathrm{B}$ (5): Amorphous beige powder. $-[\alpha]_{\mathrm{D}}^{20}-56.1^{\circ}$ (c $\left.0.12, \mathrm{MeOH}\right)$. - UV $(\mathrm{MeOH}): \lambda_{\max }(\log \varepsilon)=250(3.84), 338 \mathrm{~nm}$ (1.91). - IR (KBr): $v_{\max }=3218,3048,1642,1618,1242$, $1186 \mathrm{~cm}^{-1} .-{ }^{1} \mathrm{H}$ NMR $\left(\mathrm{CD}_{3} \mathrm{COCD}_{3}, 400 \mathrm{MHz}\right)$ and ${ }^{13} \mathrm{C}$ NMR $\left(\mathrm{CD}_{3} \mathrm{COCD}_{3}, 100 \mathrm{MHz}\right)$ : see Table II. - HR-CIMS: $m / z=463.1232$ (calcd. for $\mathrm{C}_{22} \mathrm{H}_{23} \mathrm{O}_{11}$ 463.1240).

Campylospermoside $C$ (6): Amorphous beige powder. $-[\alpha]_{\mathrm{D}}^{20}-42.1^{\circ}(c$ 0.11, $\mathrm{MeOH})$. - UV $(\mathrm{MeOH}): \lambda_{\max }(\log \varepsilon)=260(2.43), 330 \mathrm{~nm}(1.22)$.

Abouem à Zintchem A., Bikobo N. D., Atchade A. T., Ngo Mbing J., Piebo J. G., Ghogomu T. R., Blond A., Pegnyemb D. E., and Bodo B. (2008), Nitrile glycosides and serotobenine from Campylospermum glaucum and Ouratea turnarea. Phytochemistry 69, 2209-2213.

Agarwal P. K. (1989), Carbon-13 NMR of Flavonoids. Elsevier, NewYork, p. 283.

Bhat S. V., Nagasampeg B. A., and Sivakumar M. (2005), Chemistry of Natural Products. Nasura Publishing House, New Dehli, p. 585.

Carbonezi C. A., Hamerski L., Gunatilaka A. A. L., Cavalheiro A., Castro-Gamboa I., Silva S. D. H., Furlan M., Young M. C. M., Lopes M. N., and Bolzani
- IR (KBr): $v_{\max }=3198,3050,1642,1620,1238$, $1197 \mathrm{~cm}^{-1}$. - ${ }^{1} \mathrm{H}$ NMR $\left(\mathrm{CD}_{3} \mathrm{COCD}_{3}, 400 \mathrm{MHz}\right)$ and ${ }^{13} \mathrm{C}$ NMR $\left(\mathrm{CD}_{3} \mathrm{COCD}_{3}, 100 \mathrm{MHz}\right)$ : see Table III. - HR-CIMS: $m / z=479.1192$ (calcd. for $\mathrm{C}_{22} \mathrm{H}_{23} \mathrm{O}_{12}$ 479.1189).

Campylospermoside D (7): Amorphous beige powder. $-[\alpha]_{\mathrm{D}}^{20}-64.8^{\circ}$ (c $\left.0.2, \mathrm{MeOH}\right)$. - UV $(\mathrm{MeOH}): \lambda_{\max }(\log \varepsilon)=262(2.26), 320(1.82) \mathrm{nm} .-$ IR (KBr): $v_{\max }=3206,3050,1732,1642,1636,1620$, $1609,1241,1189 \mathrm{~cm}^{-1} .-{ }^{1} \mathrm{H}$ NMR $\left(\mathrm{CD}_{3} \mathrm{COCD}_{3}\right.$, $400 \mathrm{MHz})$ and ${ }^{13} \mathrm{C} \mathrm{NMR}\left(\mathrm{CD}_{3} \mathrm{COCD}_{3}, 100 \mathrm{MHz}\right)$ : see Table I. - HR-CIMS: $m / z=593.1659$ (calcd. for $\mathrm{C}_{31} \mathrm{H}_{29} \mathrm{O}_{12}$ 593.1646).

Campylospermoside $E$ (8): Amorphous beige powder. $-[\alpha]_{\mathrm{D}}^{20}-71.3^{\circ}$ (c $\left.0.21, \mathrm{MeOH}\right)$. - UV $(\mathrm{MeOH}): \lambda_{\max }(\log \varepsilon)=254(2.46), 336 \mathrm{~nm}(1.24)$.IR $(\mathrm{KBr}): v_{\max }=3431,3044,1726,1638,1632,1616$, $1603,1246,1186 \mathrm{~cm}^{-1} .-{ }^{1} \mathrm{H}$ NMR $\left(\mathrm{CD}_{3} \mathrm{COCD}_{3}\right.$, $400 \mathrm{MHz})$ and ${ }^{13} \mathrm{C}$ NMR $\left(\mathrm{CD}_{3} \mathrm{COCD}_{3}, 100 \mathrm{MHz}\right)$ : see Table II. - HR-CIMS: $\mathrm{m} / z=609.1615$ (calcd. for $\mathrm{C}_{31} \mathrm{H}_{29} \mathrm{O}_{13}$ 609.1608).

Campylospermoside $F$ (9): Amorphous beige powder. $-[\alpha]_{\mathrm{D}}^{20}-73.4^{\circ}$ (c $\left.0.24, \mathrm{MeOH}\right)$. - UV $(\mathrm{MeOH}): \lambda_{\max }(\log \varepsilon)=256(3.81), 320(2.23) \mathrm{nm}$. IR (KBr): $v_{\max }=3334,3042,1724,1642,1632,1618$, $1601,1238,1182 \mathrm{~cm}^{-1} .-{ }^{1} \mathrm{H}$ NMR $\left(\mathrm{CD}_{3} \mathrm{COCD}_{3}\right.$, $400 \mathrm{MHz})$ and ${ }^{13} \mathrm{C}$ NMR $\left(\mathrm{CD}_{3} \mathrm{COCD}_{3}, 100 \mathrm{MHz}\right)$ : see Table III. - HR-CIMS: $m / z=625.1542$ (calcd. for $\mathrm{C}_{31} \mathrm{H}_{29} \mathrm{O}_{14}$ 625.1557).

\section{Acknowledgement}

We thank Mr. Lionel Dubust for measuring the mass spectra and the University of Yaounde 1 grants committee for financial assistance.
V. S. (2007), Bioactive flavone dimers from Ouratea multiflora (Ochnaceae). Rev. Bras. Farmacogn. 17, 319-324.

Carvalho M. G., Carvalho G. J. A., and Braz-Filho R. (2000), Chemical constituents from Ouratea floribunda: Complete ${ }^{1} \mathrm{H}$ and ${ }^{13} \mathrm{C}$ NMR assignments of atranorin and its new acetylated derivative. J. Braz. Chem. Soc. 11, 143-147.

Carvalho M. G., Suzart L. R., Cavatti L. C., and Kaplan M. A. C. (2008), New flavonoids and other constituents from Ouratea hexasperma (Ochnaceae). J. Braz. Chem. Soc. 19, 1423-1428.

Daniel J. F. S., Carvalho M. G., Cardoso R. S., Agra M. F., and Eberlin M. N. (2005), Other flavonoids from 
Ouratea hexasperma (Ochnaceae). J. Braz. Chem. Soc. 16, 634-638.

Elo Manga S. S., Tih A. E., Ghogomu R. T., Blond A., and Bodo B. (2009), Biflavonoid constituents of Campylospermum manii. Biochem. Syst. Ecol. 37, 402-404.

Felicio J., Rossi M. H., Park H. R., Gonçalez E., Braggio M. M., David J. M., and Cordeiro I. (2001), Biflavonoids from Ouratea multiflora. Fitoterapia 72, 453-455.

Felicio J., Rossi M. H., Braggio M. M., Gonçalez E., Pak A., Cordeiro I., and Felicio R. C. (2004), Chemical constituents from Ouratea parviflora. Biochem. Syst. Ecol. 32, 79-81.

Gattuso G., Barreca D., Gariulli C., Leuzzi U., and Caristt C. (2007), Flavonoid composition of citrus juices. Molecules 12, 1641-1673.

Ghosal S. and Jaiswal D. K. (1980), Chemical constituents of Gentianaceae XXVIII: Flavonoids of Enicostemma hyssopifolium (Willd.) Verd. J. Pharm. Sci. 69, 53-56.

Grynberg N. F., Carvalho M. G., Velandia J. R., Oliveira M. C., Moreira I. C., Braz-Filho R., and Echevarria A. (2002), DNA topoisomerase inhibitors: biflavonoids from Ouratea species. Braz. J. Med. Biol. Res. 35, 819-822.

Gupta S. and Kohli S. (2010), Phytochemical screening of Sarcostigmma acidum. Int. J. Pharm. Life Sci. 1, $170-173$.

Jose C. I., Phadke P. S., and Rama Rao A. V. (1974), Infrared spectra of flavones and isoflavones. Effect of iodine and boron trifluoride on carbonyl frequencies. Spectrochim. Acta Part A 30, 1199-1206.

Mabry T. J., Markham K. R., and Thomas B. M. (1970), The Systematic Identification of Flavonoids. Springer Verlag, Berlin, p. 77.

Mbing J. N., Pegnyemb D. E., Tih R. G., Sondengam B. L., Blond A., and Bodo B. (2003), Two biflavonoids from Ouratea flava stem bark. Phytochemistry 63, $427-431$.

Moreira I. C., Carvalho M. G., Bastos A. F. O., and BrazFilho R. (1999), A flavone dimer from Ouratea hexasperma. Phytochemistry 51, 833-838.
Nascimento L. A. S., Guilhon G. M. S. P., Arruda M. S. P., Santos L. S., Arruda A. C., Müller A. H., Silva M. N., Silvane T. R., and Carvalho M. G. (2009), Biflavones and triterpenoids isolated from Ouratea castaneifolia (DC.) Engl., Ochnaceae. Braz. J. Pharmacogn. 19, 823-827.

Ndongo J. T., Shaaban M., Ngo Mbing J., Bikobo N. D., Atchade A. T., Pegnyemb D. E., and Laatsch H. (2010), Phenolic dimers and indole alkaloid from Campylospermum flavum. Phytochemistry 71, $1872-1878$

Ngo-Mbing J., Gueiffier C. E., Atchadé A. T., GangouéPiéboji J., Mbafor J. T., Ghogomu-Tih R., Pothier J., Pegnyemb D. E., and Gueiffier A. (2006), Two biflavonoids from Ouratea nigroviolacea. Phytochemistry 67, 2666-2670.

Park B.-Y., Min B.-S., Oh S.-R., Kim J.-H., Bae K.-H., and Lee H.-K. (2006), Isolation of flavonoids, a biscoumarin and an amide from the flower buds of Daphne genkwa and the evaluation of their anticomplement activity. Phytother. Res. 20, 610-613.

Pegnyemb D. E., Mbing J. N., Atchadé A. T., Tih R. G., Sondengam B. L., Blond A., and Bodo B. (2005), Antimicrobial biflavonoids from the aerial parts of Ouratea sulcata. Phytochemistry 66, 1922-1926.

Sharaf M., El-Ansari M. A., and Saleh N. A. M. (2000), New flavonoids from Avicennia marina. Fitoterapia 71, 274-277.

Shen Z. and Theander O. (1985), Flavonoid glycosides from needles of Pinus massoniana. Phytochemistry 24, 155-158.

Velandia J. R., Carvalho M. G., Braz-Filho R., and Werle A. A. (2002), Biflavonoids and a glucopyranoside derivative from Ouratea semiserrata. Phytochem. Anal. 13, 283-292.

Zhang Z. and Amaral M. E. (2007), Ochnaceae, Vol. 12. In: Flora of China. Science Press, Beijing, pp. $361-362$.

Zintchem A. A., Atchadé A. T., Tih R. G., Mbafor J. T., Blond A., Pegnyemb D. E., and Bodo B. (2007), Flavonoids from Ouratea staudtii Van Tiegh. ex Keay (Ochnaceae). Biochem. Syst. Ecol. 35, 255-256. 